\title{
Heterologous expression of thermostable esterase gene from Geobacillus thermoleovorans YN under different expression promoters
}

\author{
N. A. Soliman - Y. R. Abdel-Fattah • \\ H. E. Mostafa $\cdot$ A. Gaballa
}

Received: 27 August 2011/Revised: 28 January 2012/Accepted: 5 December 2012/Published online: 8 October 2013

(C) Islamic Azad University (IAU) 2013

\begin{abstract}
The gene encoding extracellular thermostable carboxylesterase (estA) from Geobacillus thermoleovorans YN was fused to six histidines and expressed under different promoters. Three different clones carrying this gene were constructed in host cell Escherichia coli BL21 (DE2) using three expression systems pET-17b, pBluescript ${ }^{\circledR}$ II $\mathrm{KS}(+)$ and pCYTEX-P1 (pET-estA T7 promoter; pBlueestA $\mathrm{T} 7$ promoter and pBlue-estA $\mathrm{T} 7$ promoter and Lambda $\mathrm{pL}$ promoter). The efficiency of expression of the three constructs was evaluated, where the highest esterase expression $(589 \mu \mathrm{mol} / \mathrm{ml})$ using $p$-nitrophenyl laurate as substrate (pNP-laurate: $\mathrm{C} 18 \mathrm{H} 27 \mathrm{NO} 4$ ) was measured under the control of T7 promoter in expression vector pET-17b after $4 \mathrm{~h}$ of the induction. A 1.5 -fold increase in enzyme activity was measured with specific activity $1,043 \mu \mathrm{mol} /$ $\mathrm{mg}$ protein on growing the clone expressed the target gene under T7 promoter (pET-estAT7) in 2-L working volume BIOFLO III bioreactor under optimal conditions. Recombinant expression of the tested thermostable esterase was monitored by sodium dodecyl sulfate polyacrylamid gel electrophoresis, zymogram and activity measurements with $\alpha$-naphthyl acetate $(\mathrm{C} 12 \mathrm{H} 10 \mathrm{O} 2)$ and Fast Red. The SDSPAGE analysis of E. coli BL21(DE3)/pET-estA lysates
\end{abstract}

N. A. Soliman $(\varangle)$ · Y. R. Abdel-Fattah · H. E. Mostafa Bioprocess Development Department, Genetic Engineering and Biotechnology Research Institute (GEBRI), City for Scientific Research and Technology Applications (SRTA-City), Alexandria, Egypt

e-mail: nadiastuttgart@yahoo.com

\section{A. Gaballa}

Environmental Biotechnology Department, Genetic Engineering and Biotechnology Research Institute (GEBRI), City for Scientific Research and Technology Applications (SRTA-City), Alexandria, Egypt indicated the presence of a protein band $(29 \mathrm{kDa})$ related to the targeted expressed gene.

Keywords BIOFLO III bioreactor - Encoding gene · Escherichia coli $\cdot$ Induction · Six histidines

\section{Introduction}

Carboxylesterases (EC 3.1.1.3) and lipases (EC 3.1.1.1) are two major classes of $\alpha / \beta$-fold hydrolases, which are widely distributed in nature. Carboxylesterases can be distinguished from lipases by their preference for short chain acyl derivatives and lack of requirement for interfacial activation (Long 1971). Both esterases and lipases have been recently used with success in media containing low water content where they catalyze new reactions such as esterification or transesterification and transformation (Kawamoto et al. 1987; Klibanov 2001; Liang et al. 2010). Heterogeneous transesterification is considered to be a green process. The process requires neither catalyst recovery nor aqueous treatment steps and very high yields of methyl esters can be obtained, close to the theoretical value. However, heterogeneously catalyzed transesterification generally requires more severe operating conditions, and the performance of heterogeneous catalysts is generally lower than that of the commonly used homogeneous catalysts (Refaat 2011).

The thermostability in water usually correlated with the resistance to denaturation in organic solvents. Therefore, the thermostability is considered an important parameter in the choice of an enzyme for the development of various industrial processes. The new application of carboxylesterases enzymes have been reviewed recently by Bornscheuer (2002), Panda and Gowrishankar (2005). Recent 
classification of these enzymes based on the biochemical properties and their application in biocatalysis has been reviewed by Bornscheuer 2002.

Although esterases (EC 3.1.1.3) are widely distributed in animals, plants and microorganisms, only little is known on the production of heat-stable esterases from thermophiles. Most commercially available esterases are produced by mesophilic bacteria and fungi, and because of the possibility of increasing stability and resistance to chemical denaturation, esterases from thermophiles are expected to play a significant role in industrial processes (Owusu and Cowan 1989; Cowan 1992). Recently, thermophilic, hyperthermophilic microorganisms and unculturable microbes via metagenome represent an ideal sources for isolating such enzyme (Wood et al. 1995; Kugimiya et al. 1992; Morana et al. 2002; Montoro-García et al. 2009; Lee et al. 2010). Many of genes related to this enzyme have been cloned, purified and characterized (Gao et al. 2003; Ewis et al. 2004; Ro et al. 2004; Karpushova et al. 2005). For the development of industrial bioprocesses for thermostable esterase production, it is crucial to evaluate the kinetic and stoichiometric parameters of microbial growth and enzyme production and to consider the operation conditions for maximum productivity. However, only limited information is available from the literature on bioprocessing data concerning esterase production. In this paper, we describe the expression of the previously identified and expressed gene encoding heat-stable esterase for Geobacillus thermoleovorans YN (Soliman et al. 2007) under different expression promoters in reference to the earlier temperature-inducible expression system. We also report scaling up the production of the recombinant heatstable esterase expressed under $\mathrm{T} 7$ promoter in 3-L BIOFLO III bioreactor with 2-L working volume.

This work was performed in City for Scientific Research and Technology Applications Alexandria, Egypt.

\section{Materials and methods}

Bacterial strains, plasmids and culture conditions

For the purpose of cloning, Escherichia coli DH5 $\alpha$ (Clontech, Heidelberg, Germany) was used as a host for the expression vector pCYTEX-P1 (ITB Stuttgart,Germany). E. coli BL21 (DE3) (Novage, Madison, WI, USA), which is protease-deficient mutant, was used as a host for the expression vectors Bluescript ${ }^{\circledR}$ II $\mathrm{KS}(+)$ and pET-17b (Novagen).

For selection of E. coli cells harboring the above-mentioned vectors carrying estA, it was grown in Luria-Bertani (LB) liquid medium or in LB agar plates supplemented with $100 \mu \mathrm{g} / \mathrm{ml}$ ampicillin at $37^{\circ} \mathrm{C}$ (Luria et al. 1960). For experiments utilizing $\alpha$-complementation, isopropyl-thio$\beta$-galactoside (IPTG) and 5-bromo-4-chloro-3-indolyl- $\beta$ D-galactopyranoside were added to LB agar media at concentration 100 and $20 \mathrm{mg} / \mathrm{l}$, respectively. LB/ampicillin, IPTG and tributyrin (1\%) agar plates were used to check for esterase activity.

DNA isolation and manipulation

Restriction analysis and DNA modifications were performed using enzymes purchased from MBI Fermentas (MBI Fermentas, St. Leo-Rot, Germany) according to the manufacturer's recommendations. Plasmid DNA was isolated using plasmid kit (ExtremePure Plasmid Isolation Kit GEBRI). Gel extraction kit was used to recover DNA fragments from agarose gels (Sephaglas ${ }^{\mathrm{TM}}$ BandPrep Kit). Recombinant DNA manipulations were carried out using standard protocols (Sambrook et al. 1989), where E. coli transformation with plasmid DNA was carried out according to a method of Chung et al. 1989.

Construction of expression vectors carried the thermostable esterase gene (estA)

The recombinant vector (pCYTEX-estA) which carries the thermostable esterase from $G$. thermoleovorans YN was used as a source, where NdeI and EcoRI recognition sites at the $5^{\prime}$ and $3^{\prime}$ ends, respectively, were introduced into the gene to produce a fragment size of $744 \mathrm{bps}$. After restriction digestion with the previously mentioned enzymes, the 744-bp fragment was ligated into the respective sites of pET-17b using T4-DNA ligase from MBI for $12 \mathrm{~h}$ at $16{ }^{\circ} \mathrm{C}$. Chemically prepared competent $E$. coli cells were transformed with the ligate and plated onto LB/ampicillin agar plates. The presence of gene in resultant plasmids was confirmed by restriction analysis and PCR using the forward (FE:5'TTCCATATGATGATGAAAATTGTTCCGC $\mathrm{CG}^{\prime}$ ) and the reverse esterase specific primers (RE:5'CC GGAATTCTTACCAATCTAACGATTCAAGAAATG3'). PCR was performed in a thermocycler (Eppendorf, PCR) with initial denaturation step $\left(95^{\circ} \mathrm{C}\right.$ for $\left.2 \mathrm{~min}\right)$, followed by 30 cycles: $95{ }^{\circ} \mathrm{C}$ for $1 \mathrm{~min}, 55^{\circ} \mathrm{C}$ for $1 \mathrm{~min}$, and $72{ }^{\circ} \mathrm{C}$ for $1 \mathrm{~min}$.

In order to prepare the construct pBlue-estA $\mathrm{T} 7$, the ends of the fragment carry the gene were repaired in an endfilling reaction using Klenow fragments of E. coli DNA polymerase for blunt-end ligation. The DNA was ligated into the blunt-end vector [pBluescript ${ }^{\circledR}$ II KS(+)] cut with $E c o R V$. Competent $E$. coli cells were transformed with the ligate and plated onto LB agar plates containing X-gal and IPTG. The white colonies were selected for plasmids isolation. Among the isolated plasmids, the esterase gene that lies under control of T7, but not T3, promoter was selected 
using the following set of primers for PCR amplification: The universal reverse primer for $\beta$-galactosidase (URP:5'AGCGGATAACAATTTCACACACGA3') and the forward esterase specific primer (FE:5'ATGGGAATTCCAT ATGATGATGAAAATTGTTCCGCCG3') at the same PCR conditions as previously described.

The third construct (pBlue-estA T7\& $\lambda \mathrm{pL}$ ) was prepared to include a hybrid of $\mathrm{T} 7$ and $\lambda \mathrm{pL}$ promoters. The $\mathrm{pCY}-$ TEX-estA was cleaved with NotI and EcoRI, where the restricted fragment $(2,238 \mathrm{bps})$ containing the $\lambda \mathrm{pL}$ promoter and the esterase gene was cut and purified from the agarose gel and inserted into respective sites of the vector pBluescript $^{\circledR}$ II $\mathrm{KS}(+)$ next to T7 promoter. Competent $E$. coli cells were transformed with the ligate and plated onto LB/ampicillin agar plates containing X-gal and IPTG, and the white colonies were selected for plasmid isolation. Restriction digestion of the purified plasmids with Not $1 /$ EcoR1 and PCR amplification with URP and FE primers were used for gene verification.

For expression, the previously constructed vectors carrying estA gene (pET-estA T7, pBlue-estA T7, pBlue-estA T7\& $\lambda \mathrm{pL}$ ) retransformed into $E$. coli BL21 (DE3), plated onto LB/ampicillin agar to obtain E. coli BL21(DE3)/pETestA T7, BL21(DE3)/pBlue-estA T7 and BL21(DE3)/ pBlue-estA T7\& $\lambda$ pL. Recombinant clones of E.coli BL21 (DE3) harboring the appropriate expression vectors were used to inoculate $5 \mathrm{ml} \mathrm{LB} /$ ampicillin and allowed to grow overnight at $37^{\circ} \mathrm{C}$ and $200 \mathrm{rpm}$. For qualitative esterase activity detection, the overnight cultures were streaked on (LB/ampicillin/IPTG agar plates supplemented with $1 \%$ tributyrin), incubated overnight at $37^{\circ} \mathrm{C}$. The appearance of halo zone is considered an indication of esterase activity (Lawrence et al. 1967).

Expression of the cloned thermostable esterase

E. coli DH5 $\alpha$ cells were freshly transformed with the expression vector pCYTEX-estA as a parent construct. Whereas, the created expression vectors (pET-estA T7, pBlue-estA $\mathrm{T} 7$ and pBlue-estA T7\& pL $\lambda$ ) were freshly transformed into E. coli BL21(DE3) and grown at $37^{\circ} \mathrm{C}$ in $50 \mathrm{ml} \mathrm{LB}$ media until the early exponential phase with optical density measured at $600 \mathrm{~nm}$ equal $0.8\left(\mathrm{OD}_{600}\right)$. The recombinant protein of pCYTEX-estA construct was induced by an increase in temperature to $42{ }^{\circ} \mathrm{C}$. However, the expression was induced with $0.4 \mathrm{mM}$ IPTG for the constructs (pET-estA T7 and pBlue-estA T7). Three different conditions of induction were applied individually in case of expression vector (pBlue-estA T7\& $\lambda \mathrm{pL}$ ), using $0.4 \mathrm{mM}$ IPTG, temperature shift to $42^{\circ} \mathrm{C}$ and $0.4 \mathrm{mM}$ IPTG with shifted temperature.

Samples were taken every $30 \mathrm{~min}$ at the tested induction conditions and the cultivation was continued for $2 \mathrm{~h}$. The cells were harvested from the collected samples by centrifugation (4,000 rpm) and washed twice with $50 \mathrm{mM}$ phosphate buffer, $\mathrm{pH}$ 7.5. E coli cell extracts were prepared by sonication ( 3 times for $5 \mathrm{~min}$ ) and used to assay esterase and protein.

\section{Bioreactor experiment}

Esterase activity and gene expression of $E$. coli BL21(DE3) harboring the plasmid pET-estA $\mathrm{T} 7$ was investigated on growing the clone in 2-L working volume BIOFLO III fermentor (New brunswick Scientific co Inc., Edison, NJ, USA) in LB/ampicillin medium. The airflow rate was $0.75 \mathrm{~L} / \mathrm{min}$, and the dissolved oxygen tension, as recorded polarographically with a $\mathrm{O}_{2}$ electrode, was maintained above $10 \%$ air saturation by automatic adjustment of the speed of the stirrer. The temperature was kept at $37^{\circ} \mathrm{C}$ and the $\mathrm{pH}$ was controlled at $\mathrm{pH}$ 7.0. The fermentor was inoculated with $10 \%$ of freshly cultured E. coli BL21(DE3)/pET-estA T7 grown in LB/ampicillin medium at $37{ }^{\circ} \mathrm{C}$ for $4 \mathrm{~h}$. Growth of culture in the fermentor was monitored by measuring the OD at $600 \mathrm{~nm}$. For induction purpose, $0.4 \mathrm{mM}$ IPTG was added to the culture at $\mathrm{OD}_{600}=1.0$. Esterase activity and protein concentration were measured in cell lysate of collected samples.

\section{Protein determination}

The protein concentration of cell lysate was measured by the Lowry method (Lowry et al. 1951) with bovine serum albumin as the standard and all measurements are the mean of three determinations.

\section{SDS-PAGE}

Protein from the crude extracts were analyzed by sodium dodecyl sulfate polyacrylamide gel electrophoresis (SDSPAGE) according to Laemmli (1970). A low molecular weight (LMW) standard (MBI, Fermentas) was used as a reference.

\section{Esterase activity}

The esterase activity of the crude extracts was determined spectrophotometrically using $p$-nitrophenyl laurate (SigmaAldrich Chemie GmbH, Germany) as substrate. All activity measurements were performed in triplicates and expressed as the arithmetic mean of measurements. A volume of $25 \mu \mathrm{l}$ appropriately diluted sample was dissolved in $725 \mu \mathrm{l}$ phosphate buffer (50 mM, pH 7.2). The enzymatic reaction was carried out at $60{ }^{\circ} \mathrm{C}$ after addition of $100 \mu$ substrate solution ( $25 \mathrm{mM} p$-nitrophenyl laurate in absolute ethanol). After $10 \mathrm{~min}$ of incubation, $250 \mu \mathrm{l}$ of $100 \mathrm{mM} \mathrm{Na}_{2} \mathrm{CO}_{3}$ 
was added and the mixture was centrifuged at $4{ }^{\circ} \mathrm{C}(10 \mathrm{~min}$ $13,000 \mathrm{rpm})$. The absorbance of librated $p$-nitrophenol was measured at $420 \mathrm{~nm}$. 1 unit (U) of esterase activity is defined as the amount of enzyme that causes the release of $1 \mu \mathrm{mol}$ of $p$-nitrophenol/min under test conditions (Becker et al. 1997).

Esterase activity was visualized on zymogram, using $8 \%$ SDS-polyacrylamide gel. The enzyme preparation samples were separated by SDS-PAGE and the gel was renaturated in $100 \mathrm{mM}$ Tris- $\mathrm{HCl}$ buffer, $\mathrm{pH} 7.5$, containing $0.5 \%$ Triton X-100 for $1 \mathrm{~h}$ at room temperature. After washing the gel with deionized water, it was incubated for $5 \mathrm{~min}$ in developing solution consisting of $3 \mathrm{mM} \alpha$-naphthyl acetate, $1 \mathrm{mM}$ Fast Red TR (Sigma) and $100 \mathrm{mM}$ Tris- $\mathrm{HCl}$ buffer, $\mathrm{pH}$ 7.5. Esterase activity was detected by the appearance of brown-colored band in the gel (Krebsfanger et al. 1998; Schmidt-Dannert et al. 1996).

\section{Results and discussion}

Construction, expression of thermostable esterase under different expression promoters

The thermostable esterase gene (estA) from G. thermoleovorans $\mathrm{YN}$ was previously expressed under the control of the strong temperature-inducible $\lambda \mathrm{pL}$ promoter by Soliman et al. 2007. In this experiment, the gene encoding $G$ thermoleovorans $\mathrm{YN}$ thermostable esterase gene (estA) was excised from E. coli expression vector pCYTEX-P1 for creation of new constructs carrying the gene. Three subsequent steps were followed to obtain three different fragments carry the gene (Fig. 1a). The first-developed fragment was ligated into $N d e \mathrm{I} / E o R \mathrm{I} / \mathrm{pET}-17 \mathrm{~b}$ and produced $\mathrm{pET}$ estA T7 (Fig. 1b). Whereas, both second and third fragment were ligated into $E c o R \mathrm{~V} / \mathrm{pBluescript}{ }^{\circledR} \mathrm{II} \mathrm{KS}(+)$ and NotI/ EoRI/pBluescript ${ }^{\circledR} \mathrm{II} \mathrm{KS}(+)$ and produced pBlue-estA $\mathrm{T} 7$ and pBlue-estA T7\& $\lambda \mathrm{pL}$, respectively (Fig. 1c, d). The plasmids were transformed into $E$. coli $\mathrm{BL} 21(\mathrm{DE} 3)$ to obtain the three new constructs, namely $E$. coli BL21(DE3)/pETestA T7, E. coli BL21(DE3)/pBlue-estA $\mathrm{T} 7$ and E. coli BL21(DE3)/pBue-estA T7\& $\lambda$ pL) (Fig. 1b-d). After induction, the expression under these different promoters was monitored quantitatively using pNP-laurate as substrate (complete data not shown). Compared to the earlier construct $(E$. coli DH5 $\alpha / \mathrm{pCYTEX}$-estA $\lambda \mathrm{pL}$ ), the highest expression $(470 \mu \mathrm{mol} / \mathrm{ml})$ was obtained when the gene expressed under pET-T7 promoter then under pBlue-T7 promoter $(171 \mu \mathrm{mol} / \mathrm{ml})$. The least expression $(20 \mu \mathrm{mol} /$ $\mathrm{ml})$ was observed when a hybrid promoter $(\mathrm{T} 7$ and $\lambda \mathrm{pL})$ applied. Additionally, the recombinant expression of estA gene under pET-T7 promoter was monitored by SDS-
PAGE. The SDS-PAGE analysis of E. coli BL21(DE3)/ pET-estA T7 lysate indicated the presence of a protein band $(29 \mathrm{kDa})$ was progressively increased by time (Fig. 2lane 1-4). As expected, this band corresponds to the earlier active recombinant (estA) which was purified (Fig. 2, lane 5,6) in a single step to electrophoretic homogeneity by IMAC (Soliman et al. 2007). It is worth to mention that the protein separation by electrophoresis of the observed leaky expression (E. coli BL21(DE3)/pBue-estA T7\& $\lambda \mathrm{pL}$ ) showed no induced band, while moderate expression clone (E. coli BL21(DE3)/pBlue-estA T7) produced a mildexpressed band (data not shown).

\section{Expression of EstA gene under $\mathrm{T} 7$ promoter}

In this experiment, the freshly prepared preculture of E. coli BL21(DE3)/pET-estA T7 was used to inoculate $50 \mathrm{ml} \mathrm{LB}$ ampicillin medium and allowed to grow at $37{ }^{\circ} \mathrm{C}$ with shaking $(200 \mathrm{rpm})$ until $\mathrm{OD}_{600}=1.0$. At this point, the expression was induced by lactose analogue (IPTG, $0.4 \mathrm{mM})$ and D-lactose plus lactose analogue (10, $0.4 \mathrm{mM})$, respectively. In both cases, the expression of the gene was monitored at interval $1 \mathrm{~h}$ for $5 \mathrm{~h}$ and showed in Fig. 3. Compared to the expression of $E$. coli DH5 $\alpha /$ pCYTEXesta $\lambda \mathrm{pL}$ (induced by shift of temperature to $42^{\circ} \mathrm{C}$ ), the construct E. coli BL21(DE3)/pET-estA T7 showed higher expression along all tested intervals. The highest expression $(589 \mu \mathrm{mol} / \mathrm{ml})$ was observed after $4 \mathrm{~h}$ of induction with IPTG alone. On the other hand, maximum expression $(517 \mu \mathrm{mol} / \mathrm{ml})$ was attained after $4 \mathrm{~h}$ (Fig. 3) using both Dlactose and IPTG.

\section{Bioreactor experiment}

The preculture of E.coli BL21(DE3) harboring the plasmid pET-estA T7 was cultivated in a 3-L BIOFLO III containing 2-L LB/ampicillin medium. The expression was induced with IPTG $(0.4 \mathrm{mM})$ at $\mathrm{OD}_{600 \mathrm{~nm}}(1.0)$. Samples were withdrawn from sampling gauge at different time intervals and assayed for cell growth $\left(\mathrm{OD}_{600} \mathrm{~nm}\right)$, protein concentration and esterase activity using pNP-laurate as substrate. A typical profile is shown in Fig. 3, where esterase production started after IPTG induction and increased continuously, reaching a maximum after $4.3 \mathrm{~h}$ of induction in correlation to the cell growth and specific enzyme activity as showed in Fig. 4. Furthermore, SDSPAGE and zymogram of the highest recombinant expression $(799 \mu \mathrm{mol} / \mathrm{ml})$ were applied and showed in Fig. 5 (lane 1-3).

Several intra- and extracellular carboxylesterases have been cloned, fully expressed or even partially characterized from various thermophiles (Amaki et al. 1992; Kim et al. 


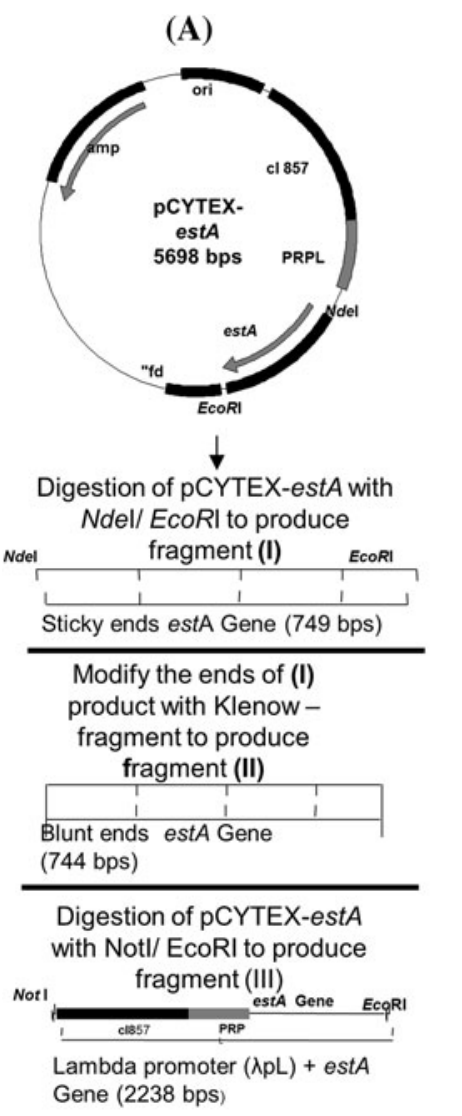

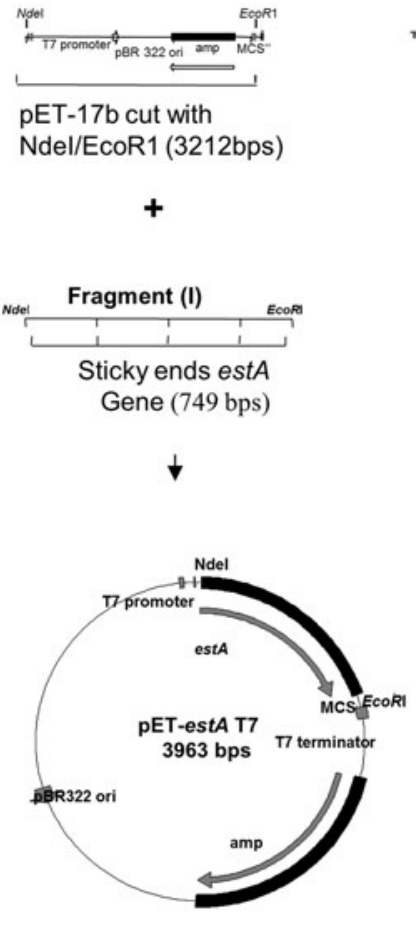

(B)
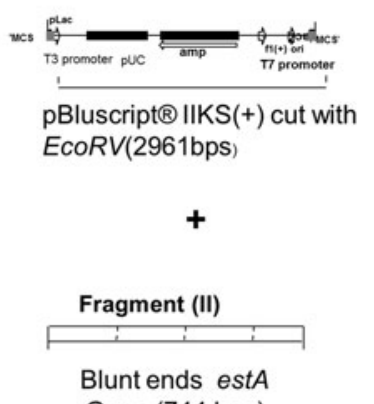

Gene (744 bps)

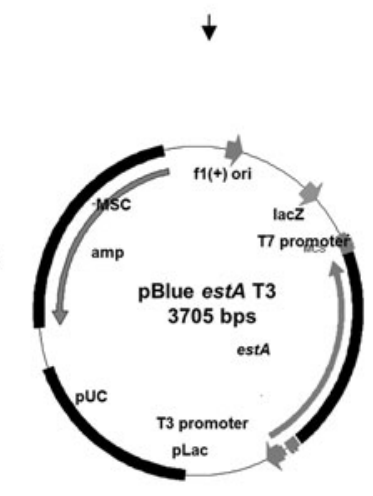

(C)
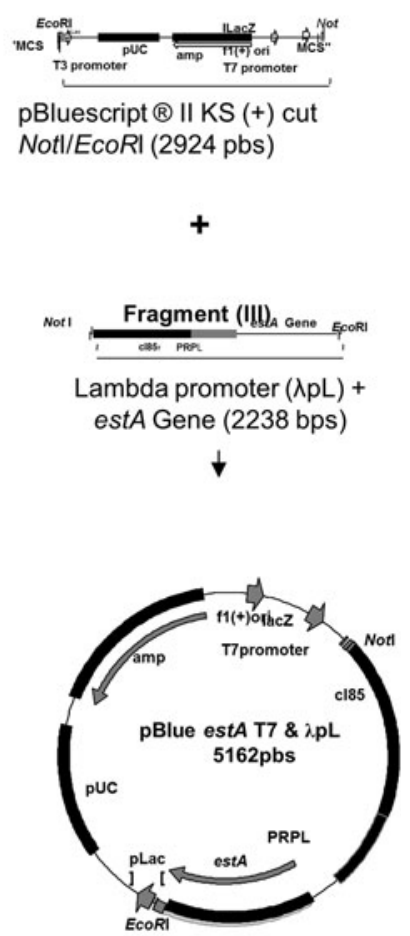

(D)

Fig. 1 Construction of different expression vectors carried the (estA) gene derived from pCYTEX-estA construct (a). The produced constructs (b, c) and (d) are pET-estA T7; pBlu-estA T7 and pBlu-estA T7 $+\lambda \mathrm{pL}$, respectively

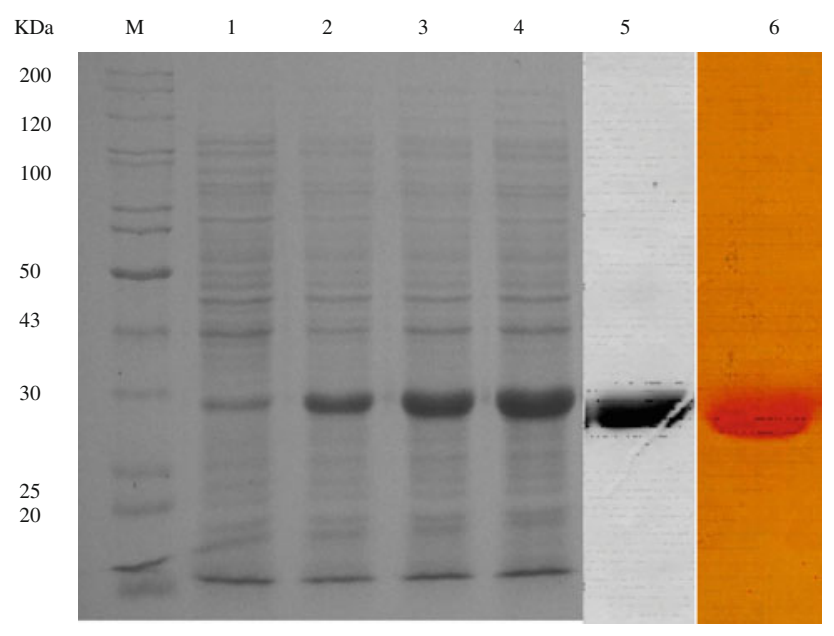

Fig. 2 Expression of the thermostable esterase (estA) in E. coli BL21(DE3) under T7 promoter (E. coli BL21/pET-estA T7). Protein samples were separated in $10 \%$ SDS-polyacrylamide gels and stained with Coomassie blue (lanes $1-5$ ) and $\alpha$-naphthyl acetate and Fast Red (zymogram) (lane 6). M: Low molecular weight protein standard (Fermentas); cell lysate of E. coli BL21/pET-estA T7 before induction (lane 1); after 1-, 1.5- and 2-h induction, respectively (lane 2-4); fraction after IMAC of a previously purified recombinant estA protein (Soliman et al. 2007) (lane 5, 6)

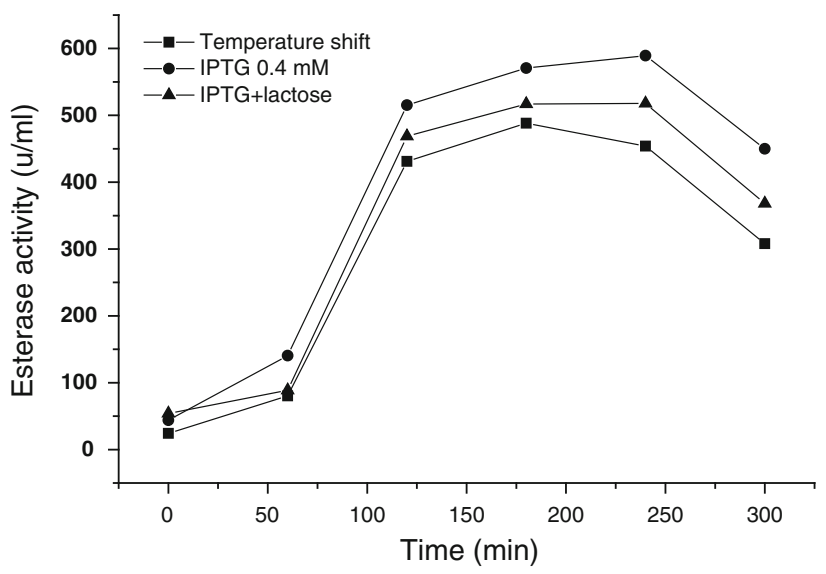

Fig. 3 Monitoring the expression of thermostable esterase with (BL21(DE3)/pET-estAT7) at different induction conditions and compared to the original construct (pCYTEX-estA $\lambda \mathrm{pL}$ ). Esterase activity was assayed using pNP-laurate on cell lysate and expressed as an average of three measurements

1997; Morana et al. 2002; Gao et al. 2003; Ewis et al. 2004). This paper describes the expression of carboxylesterase from $G$. thermoleovorans YN under different expression promoters (pET-T7, pBlue-T7 and T7\& $\lambda \mathrm{pL}$ ). 


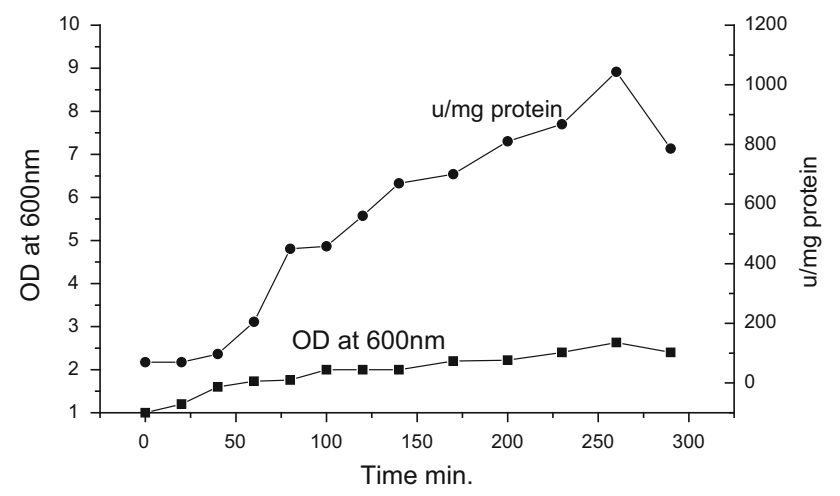

Fig. 4 Growth and specific activity of the expressed thermostable esterase with (E. coli BL21(DE3)/pET-estA T7) under scaling up the expression in 3-1 fermentor. Esterase activity was assayed using pNPlaurate on cell lysate and expressed as an average of three measurements

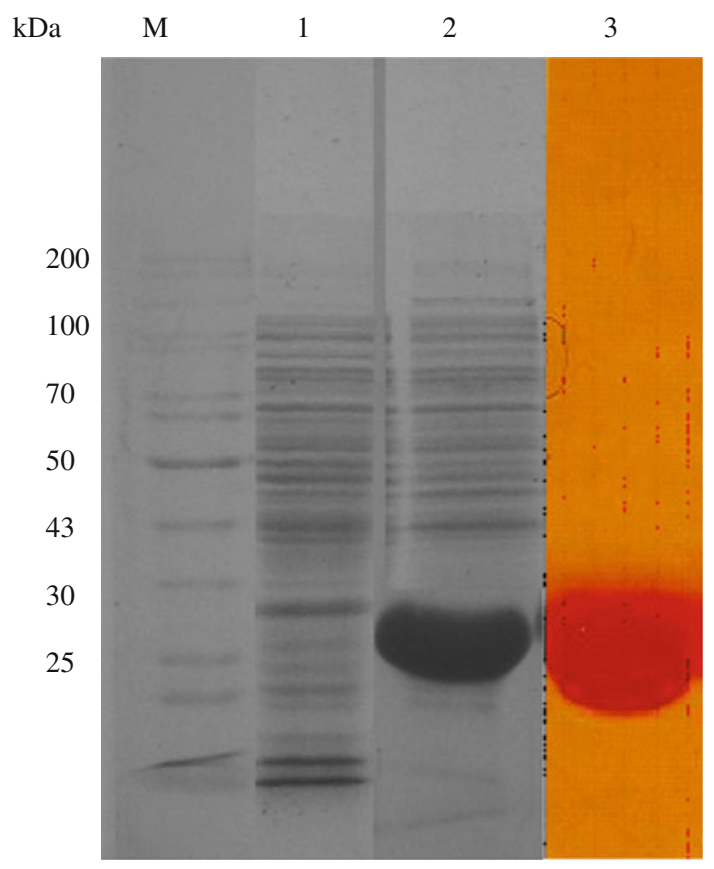

Fig. 5 Scaling up the expression of the thermostable esterase (est) in E. coli BL21(DE3) under T7 promoter (E. coli BL21/pET-estT7). Protein samples were separated in $10 \%$ sodium dodecyl sulfate (SDS)-polyacrylamide gels and stained with Coomassie blue (lanes 1-2) and $\alpha$-naphthyl acetate and Fast Red (zymogram) (lane 3). M: Low molecular weight protein standard (Fermentas); cell lysate of E. coli BL21/pET-est T7 before induction (lane 1); after 4.2-h induction in 3-1 fermentor (lane 2)

The parent gene developed from a previously constructed library of $G$. thermoleovorans $\mathrm{YN}$ and expressed under strong temperature-inducible promoter $(\lambda \mathrm{pL})$ (Soliman et al. 2007). The gene under investigation was successfully expressed under $\lambda \mathrm{pL}$, pET-T7 and pBlue-T7 promoters; however, expression under the control of the hybrid promoters $(\mathrm{T} 7 \& \lambda \mathrm{pL})$ failed. The highest efficiency of expression was obtained under $\mathrm{T} 7$ promoter in $\mathrm{pET}-17 \mathrm{~b}$ vector followed by $\lambda \mathrm{pL}$ in pCYTEX-P1 vector then T7 promoter in pBluescript ${ }^{\circledR} \mathrm{II} \mathrm{KS}(+)$. The pET series cloning and expression vector utilize the T7 RNA polymerase to express the cloned DNA under the control of T7 ploymerase in E. coli. This system is very popular for heterologous protein expression. The pET vectors are PBR322 derivatives, multicopy plasmid widely used as a cloning vehicle (Sambrook et al. 1989). pET plasmids are capable of expressing a wide variety of genes from prokaryotic and eukaryotic sources (Studier et al. 1990). Such plasmids are said to replicate in a relaxed fashion. The plasmids carry pMBI or ColE1 replicon which does not require plasmidencoded functions', rely on enzymes supplied by the host. Similarly Gao et al. (2003) and Karpushova et al. (2005) were efficiently expressed novel esterases under the control of T7 promoter using the vector pET-11a and pET-22b(+), respectively.

On the other hand, we cannot ascribe the observed unsuccessful expression under a hybrid promoter to a specific reason, especially the $\lambda \mathrm{pL} \& \mathrm{~T} 7$ promoters worked successfully when used individually. It could be attributed to the far distance between $\mathrm{T} 7$ promoter and the gene under investigation. In addition, the pBlu $\mathrm{T} 7$ promoter was showed relatively weak expression when used individually. Also, the fused lambda promoter could not show any sense on expression; however, it worked very well when it was applied alone.

In order to test the use of D-lactose, as a cheap carbon source on induction of expression, two cases were performed the use of IPTG alone and IPTG with D-lactose. The first case which used IPTG (D-lactose analogue) improved the expression, whereas the second case used (D-lactose together with IPTG) caused weakness in expression and shortage the time for maximum expression. This could be related to the blocking of receiving sites by the substrate, giving no chance for further expression by extending the time. Supposing that the enriched LB containing D-lactose, that IPTG its analogue, would induce LACUV 5 gene and render T7RNA polymerase expressed.

\section{Conclusion}

So far, there is deficiency in literature that deals with the production of heat-stable esterase on large scale. This information is very important for the development of a bioprocess for the production of any required products. So that, in this paper, we deal with the over-expression and scaling up the production of recombinant heat-stable esterase. The over-expression was attained under $\mathrm{T} 7$ promoter and the yield increased to 1.5 -fold when scaling up was performed in 3-L BIOFLO III fermentor with 2-L working volume. 
Acknowledgments The work was kindly supported by City for Scientific Research and Technology Applications.

\section{References}

Amaki Y, Tulin EE, Ueda S, Ohmiya K, Yamane T (1992) Purification and properties of a thermostable esterase of Bacillus stearothermophilus produced by recombinant Bacillus brevis. Biosci Biotechnol Biochem 56(2):238-241. http://ci.nii.ac.jp/ naid/110002680496

Becker P, Abu-Reesh I, Markossian S, Antranikian G, Markl H (1997) Determination of the kinetic parameters during continuous cultivation of he lipase-producing thermophile Bacillus sp. IHI-91 on olive oil. Appl Microbiol Biotechnol 48:184-190. www.springerlink.com/index/FWJ6EC1WXW3AQPT2

Bornscheuer UT (2002) Microbial carboxylesterases: classification, properties and application in biocatalyses. FEMS Microbiol Rev 26:73-81. http://www.ncbi.nlm.nih.gov/pubmed/12007643

Chung CT, Niemela SL, Miller RH (1989) One-step preparation of competent Escherichia coli: transformation and storage of bacterial cells in the same solution. Proc Natl Acad Sci USA 86(7):2172-2175. http://www.ncbi.nlm.nih.gov/pmc/articles/ PMC286873/

Cowan DA (1992) Biochemistry and molecular biology of the extremely thermophilic archaeobacteria. Biochem Soc Symp 58:135-147

Ewis HE, Abdelal AT, Lu C-D (2004) Molecular cloning and characterization of two thermostable caroxylesterases from Geobacillus stearothermophilus. Gene 329:187-195. http:// www.ncbi.nlm.nih.gov/pubmed/15033540

Gao R, Feng Y, Ishikana K, Ishida H, Ando S, Kosugi Y, Cao S (2003) Cloning, purification and properties of a hyperthermophilic esterase from archaeon Aeropyrum pernix KL. J Mol Catal B 24/25:1-8. abbs.oxfordjournals.org/content/early/2010/03/03/ abbs.gmq020.full

Karpushova A, Brummer F, Barth S, Lange S, Schmid RD (2005) Cloning recombinant expression and biochemical characterization of novel esterases from Bacillus sp. Associated with the marine sponge Aplysina aerophoba. Appl Microbiol Biotechnol 67:59-69. http://www.ncbi.nlm.nih.gov/pubmed/15614567

Kawamoto T, Sonomoto K, Tanaka A (1987) Esterification in organic solvents: selection of hydrolases and effect of reaction conditions. Biocatalysis 1:137-145. http://informahealthcare.com/doi/ abs/10.3109/10242428709040138

Kim H, Park S, Oh T (1997) Purification and partial characterization of thermostable carboxylesterase from Bacillus stearothermophilus L1. J Microbial Biotechnol 7(1):37-42. http://agris.fao. org/agris-search/search/display.do?f=1997/KR/KR97018.xml;KR 9702599

Klibanov AM (2001) Improving enzymes by using them in organic solvents. Nature 409:241-246. http://www.nature.com/nature/ journal/v409/n6817/abs/409241a0.html

Krebsfanger N, Zocher F, Altenbuchner J, Bornscheuer UT (1998) Characterization and enantioselectivity of a recombinant esterase from Pseudomonas fluorescens. Enzyme Microb Technol 22 (7):641-646. http://www.fstadirect.com/GetRecord.aspx?AN= 1998-09-Bg 1214

Kugimiya W, Otani Y, Hashimoto Y (1992) Molecular cloning and structure of the gene for Esterase from Thermophilic Bacterium Bacillus stearothermophilus IFO 12550. Biosci Biotechnol Biochem 56(12):2074-2075. http://www.ncbi.nlm.nih.gov/pubmed/ 1369099

Laemmli UK (1970) Cleavage of structural proteins during the assembly of the head of bacteriophage T4. Nature 227:680-685. http://www.nature.com/nature/journal/v227/n5259/abs/227680a0. html

Lawrence RC, Fryer TF, Reiter B (1967) Rapid method for the quantitative estimation of microbial of microbial lipases. Nature (London) 213:1264-1265. http://www.nature.com/nature/ journal/v213/n5082/abs/2131264a0.html

Lee MH, Hong KS, Malhotra S, Park JH, Hwang EC, Choi HK, Kim YS, Tao W, Lee SW (2010) A new esterase EstD2 isolated from plant rhizosphere soil metagenome. Appl Microbiol Biotechnol 88(5):1125-1134. http://www.ncbi.nlm.nih.gov/pubmed/206837 20

Liang B, Zhao YK, Lu P, Li SP, Huang X (2010) Biotransformation of the diphenyl ether herbicide lactofen and purification of a Lactofen Esterase from Brevundimonas sp. LY-2. J Agric Food Chem 58(17):9711-9715. http://pubs.acs.org/doi/abs/10.1021/ jf101974y

Long C (1971) Biochemists handbook. Redwood, London, pp 273-274

Lowry OH, Rosebrough NJ, Farr LA, Randall RJ (1951) Protein measurement with the Folin phenol reagent. J Biol Chem 193:265-275. http://www.jbc.org/content/193/1/265.full.pdf+ html

Luria SE, Adams JN, Ting RC (1960) Transduction of lactose utilizing ability among strains of E. coli and S. dysentria and the properties of the transducing phage particle. Virology $12: 390-438$

Montoro-García S, Martínez-Martínez I, Navarro-Fernández J, Takami H, García-Carmona F, Sánchez-Ferrer A (2009) Characterization of a novel thermostable carboxylesterase from Geobacillus kaustophilus HTA426 shows the existence of a new carboxylesterase family. J Bacteriol 19(9):3076-3085. http://www.ncbi.nlm.nih.gov/pubmed/19304850

Morana A, Prizito ND, Aurilia V, Rossi M, Cannio R (2002) A carboxylesterase from the hyperthermophilic archaeon Sulfolobus solfataricus: cloning of the gene and characterization of the protein. Gene 283(1-2):107-115. http://www.ncbi.nlm.nih.gov/ pubmed/11867217

Owusu RK, Cowan DA (1989) Correlation between microbial protein thermostability and resistance to denaturation in aqueous: organic solvent two-phase systems. Enzyme Microb Technol 11(9):568-574. http://eprints.ulster.ac.uk/14682/

Panda T, Gowrishankar BS (2005) Production and applications of esterases. Appl Microbiol Biotechnol 67(2):160-169. http:// www.springerlink.com/content/xvlvclrkey1whq09/

Refaat AA (2011) Biodiesel production using solid metal oxide catalysts. Int J Environ Sci Tech 8:203-221. http://www.ijest. org/jufile?c2hvd1BERj00NzI=\&ob= 09304388b36cb6d488838c7ddc1b0560\&fileName=full_text.pdf

Ro HS, Hong HP, Kho BH, Kim S, Chung BH (2004) Genome-wide cloning and characterization of microbial esterases. FEMS Microbiol Lett 233(1):97-105. http://onlinelibrary.wiley.com/ doi/10.1016/j.femsle.2004.01.046/full

Sambrook J, Fritsch EF, Maniatis T (1989) Molecular cloning: a laboratory manual. Cold Spring Harbor Laboratory Press, Cold Spring Harbor

Schmidt-Dannert C, Rua ML, Atomi H, Schmid RD (1996) Thermoalkalophilic lipase of Bacillus thermocatenulatus. 1. Molecular cloning, nucleotide sequence, purification and some properties. Biochim Biophys Acta 1301:105-114. http://www. ncbi.nlm.nih.gov/pubmed/8652645

Soliman NA, Knoll M, Abdel-Fattah YR, Schmid RD, Lange S (2007) Molecular cloning and characterization of thermostable esterase and lipase from Geobacillus thermoleovorans YN isolated from desert soil in Egypt. Process Biochem 42(7):1090-1100. http://cat.inist.fr/?aModele=afficheN\&cpsidt $=$ 18911423 
Studier FW, Rosenberg AH, Dunn JJ, Dubendorff JW (1990) Use of T7 RNA polymerase to direct expression of cloned genes. Methods Enzymol 185:60-89. http://www.ncbi.nlm.nih.gov/ pubmed/2199796
Wood ANP, Femandez-Lafuente R, Cowan DA (1995) Purification and partial characterization of a novel thermophilic carboxyl esterase with high mesophilic specific activity. Enzyme Microbiol Technol 17:816-825. http://www.ncbi.nlm.nih.gov/pubmed/7576531 